\title{
'It is not worse than a flu' - COVID-19 Scepticism and the Role of Trust and Far-Right Attitudes in Germany
}

\author{
Anne Küppers \& Marion Reiser \\ Department of Political Science, University of Jena, Germany
}

Carl-Zeiss-Str. 3, 07743 Jena, Germany

\begin{abstract}
Whereas previous social science scholarship on the COVID-19 pandemic has primarily focused on health behaviour, social distancing, or pandemic-related conspiracy beliefs, we investigate the drivers of COVID-19 scepticism. COVID-19 sceptics view the virus as harmless (i.e., not worse than a casual flu). Using data from a representative survey conducted in the East German region of Thuringia in autumn 2020, we show that farright political attitudes and low trust in political institutions are crucial drivers of
\end{abstract} COVID-19 scepticism.

Keywords: COVID-19, conspiracy belief, science scepticism, far-right, political trust

Word count: 8,137

This manuscript is a preprint and has not been peer reviewed. Submitted to a journal for review on 30 June 2021.

\section{Introduction}

The spread of the COVID-19 pandemic was accompanied by a spread of disinformation, leading the World Health Organization (WHO) director to conclude 'we're not just fighting an epidemic, we're fighting an infodemic' (WHO, 2020). Among the false information about the coronavirus, claims that negated or trivialised the threat posed by the virus have been prominent (Krings et al., 2021). Frequent claims are that the virus is not worse than a casual flu or that it is a hoax (Latkin et al. 2021; Pennycook et al., 2021). Attitudes that deny or downplay the seriousness of the illness have been conceptualised as COVID-19 scepticism (Latkin et al. 
2021). Understanding the drivers of these sceptic attitudes is of high relevance: Studies documented that Corona sceptics are less likely to adopt preventive behaviour (such as wearing facemasks, or staying at home), and oppose political measures to mitigate the pandemic (Latkin et al., 2021; Reiser et al., 2021; Rothmund et al., 2020). This means that these individuals can become 'critical disease vectors' (Latkin et al., 2021) if they get infected and ignore social distancing and quarantine rules (see also Lange \& Monscheuer, 2021). COVID-19 scepticism thus endangers the successful containment of the virus.

In addition, COVID-19 sceptics pose a serious challenge to representative democracy: although a broad majority usually supported lockdown measures, anti-lockdown protests took place worldwide (Carnegie Endowment 2021). Germany witnessed frequent public protests, whereby several major events attracting between 10,000 and 30,000 participants were organised by a movement called 'Querdenken' (in English: 'Lateral Thinking') (De Weck, 2020). Media reports point to an overlap between anti-lockdown protesters and right-wing extremists. It has been suggested that these anti-lockdown protests could provide fertile ground for radicalisation (DW, 2021a, c) which could lead to a growth in the number of people with far-right attitudes. Furthermore, sceptic attitudes seem to be linked to low trust in political institutions (e.g., Reinemann et al., 2020).

Despite this relevance, sceptic attitudes towards the coronavirus have hardly been studied (see Lange \& Monscheuer, 2021; Latkin et al., 2021; Rothmund et al., 2020; Stanley et al., 2020 for exceptions) as most research either focuses on health behaviour and social distancing (e.g., Plohl \& Musil, 2021; Allcott et al., 2020; Gollwitzer et al., 2020) or pandemicrelated conspiracy beliefs (Bruder \& Kunert, 2020; Uscinski et al., 2020). This article aims to fill this gap and wants to understand the phenomenon of COVID-19 scepticism more closely. Therefore, we investigate the drivers of COVID-19 scepticism. This is also relevant since it is assumed that COVID-related scepticism is fuelled by similar factors than other forms of science scepticism (e.g., Dryhurst et al., 2020; Rutjens et al., 2020). Thus, the findings will add 
knowledge to the boarder literature on science scepticism. This is crucial since science scepticism is on the rise (e.g., Rutjens et al., 2018a). To answer our research question, we rely on data from a representative survey conducted in the East German region of Thuringia in autumn 2020. This is an interesting case since Thuringia had hardly been affected prior to the survey period, which might result in lower levels of risk perception. But at the same time, farright attitudes and support for the radical right-wing populist party AfD are comparatively high (Weisskircher, 2020), which might drive COVID-19 scepticism. Based on multivariate analyses, we find that individuals who hold far-right political attitudes and have low trust in political institutions are more likely to endorse COVID-19 scepticism.

\section{Review of the literature and hypotheses}

There has been a growing interest and relevance to study the phenomenon of COVID-19 scepticism during the pandemic. According to a definition by Latkin et al., COVID-19 scepticism 'can be conceptualized as the denial of the seriousness of the illness and the perception that the pandemic is overblown or a hoax' (2021, p. 1). However, there are indications of different types of COVID-19-scepticism, which might have different drivers and predictors. Therefore, they should be conceptually and empirically distinguished. By using the conceptual work on climate change sceptics (Rahmstorf, 2004), one can distinguish between trend, attribution, and impact sceptics. With regard to the coronavirus, trend sceptics deny that there is a pandemic or a virus at all. The pandemic is seen as a hoax and as manufactured, e.g., by the political elites to deprive the citizens of their basic rights and install a dictatorship (for studies testing the belief that COVID-19 is a hoax, see e.g., Pennycook et al., 2020; Stanley et al., 2020). In contrast, attribution sceptics acknowledge the threat posed by the coronavirus. However, they deny its natural origins and claim for instance that the virus was purposefully manufactured e.g., as a bioweapon in a Chinese lab (see e.g., Banai et al., 2020; Pennycook et 
al., 2020; Schaeffer, 2020). Impact sceptics see the virus as harmless and typical beliefs include that the virus is seen as not worse than a casual flu (see e.g., Latkin et al., 2021, Banai et al., 2020; Pennycook et al., 2020). This paper focuses exclusively on the latter type since existing research points to different determinants for these types of scepticism. The focus on impact sceptics is motivated by two considerations. First, whereas trend and impact scepticism are likely associated with viewing no or only a minor threat to one's health and the health of fellow citizens, attribution scepticism is likely to be associated with perceiving the virus as especially dangerous and, thus, greater worries about one's own and other peoples' health. Imhoff and Lamberty (2020), for example, show that attribution scepticism leads to more prepping behaviour. Therefore, these beliefs should be clearly separated, and we expect only trend and impact scepticism to have a negative effect on relevant health behaviours. Second, the claim that COVID-19 is not worse than a casual flu is a more widespread belief than seeing the coronavirus as a hoax. A study by Pennycook et al. (2020), for example, finds that, whereas the first belief was shared by 12 to 20 per cent of people in Canada, the UK, or the US, the latter opinion was voiced by less than two per cent of the respondents (see for similar patterns Latkin et al., 2021).

Research on sceptic attitudes towards the coronavirus has focused mainly on two aspects: First, on health behaviour and social distancing (e.g., Plohl \& Musil, 2021; Allcott et al., 2020; Gollwitzer et al., 2020); and second on pandemic-related conspiracy beliefs (Bruder \& Kunert, 2020; Eberl et al., 2020; Uscinski et al., 2020). In contrast, little is known about the drivers for COVID-19 sceptic attitudes (for exceptions see Lange \& Monscheuer, 2021; Latkin et al., 2021; Rothmund et al., 2020). Furthermore, results from existing public opinion studies on Corona scepticism and health behaviour need to be treated with caution because the studies often sampled non-representative populations (e.g., online convenience samples or Amazon Mechanical Turk workers). This article aims to fill this gap and wants to understand the phenomenon of COVID-19 scepticism more closely. This is of high relevance as COVID-19 
sceptics are shown to adopt less health behaviour to stop the spread of the virus (e.g., staying at home, wearing facemasks) and oppose political measures to contain the virus (Latkin et al., 2021; Reiser et al., 2021; Rothmund et al., 2020), which are crucial to mitigate the pandemic (e.g., Li et al. 2020). Such behaviour poses a serious public health risk to society as a whole, especially in societies with a high share of elderly people (such as in Thuringia) or more vulnerable health care systems. Moreover, in light of an increase of different forms of science scepticism during the last years, it is important to understand the factors fuelling COVIDrelated scepticism as one specific form of science scepticism (e.g., Dryhurst et al., 2020; Rutjens et al., 2020). Therefore, the results will also add knowledge to the broader literature on science scepticism.

\section{Explanations for COVID-19 Scepticism}

So far, there is only limited research on the determinants of COVID-19 scepticism. However, it is argued that COVID-related scepticism is a specific form of science scepticism (Rutjens et al., 2021) which allows to draw on these findings to develop hypotheses on COVID-19 scepticism. While it has been stressed that science scepticism is heterogeneous with regard to its predictors (Rutjens \& van der Lee, 2020; Rutjens et al., 2018b), it nevertheless has been argued that existing research on science scepticism and, in particular on climate change scepticism can inform scholarship on COVID-19 scepticism (Packer et al., 2021; Rutjens et al., 2021). From a review of the existing literature, we can derive explanations for COVID-19 scepticism on four dimensions: risk perception, political ideology, conspiracy beliefs, and mistrust towards institutions and/or the political system. 


\section{Risk perception}

Regarding the coronavirus, several studies point to an impact of risk perception on COVID-19 scepticism in two dimensions. The first dimension relates to the perceived threat by the coronavirus itself. Dryhurst et al. observe that 'people who have had direct personal experience with the virus perceive more risk compared to those who have not had direct experience' (2020, p. 998). Latkin et al. (2021) show that people who were less worried that people close to them would die were more likely to agree with COVID-19 sceptic statements ${ }^{1}$. From this, we can hypothesise that those who perceive a greater risk by the coronavirus to their own health may be less likely to endorse Corona sceptic views.

Therefore, our first hypothesis reads as:

- H1a: The more individuals perceive COVID-19 as a risk to their health the less likely they are Corona sceptics.

The second dimension of risk perception refers to the effects of the measures to mitigate the pandemic on the economy and the labour market in particular. These lockdown measures cause economic activities and businesses to be put on hold (McKee \& Stuckler, 2020; Naumann et al., 2020) and lead to unemployment and short-time work (e.g., Fuchs-Schündeln et al., 2020). Concerning climate change scepticism, research shows that economic interests and risk perception influence scepticism (Lejano \& Dodge, 2017; Rutjens et al., 2021). In line with these findings, one can also assume that the more individuals perceive COVID-19 and the policies to mitigate the pandemic as a threat to their personal economic situation, the more likely they are COVID-19 sceptics. Hence, hypothesis $1 \mathrm{~b}$ reads:

\footnotetext{
${ }^{1}$ As Latkin et al. (2021) point out, the relationship between the perception of a risk to one's health and COVID19 scepticism could, however, be bidirectional: those who are sceptical and trivialise the virus will not perceive the coronavirus as a threat to their health; if people do not feel personally at risk, they might be more likely to endorse sceptical statements about the virus.
} 
- H1b: The more individuals perceive the mitigation of the COVID-19 pandemic as a risk to their economic situation, the more likely they are Corona sceptics.

\section{Political ideology}

A second potential driver for COVID-19 scepticism is political ideology. Recent scholarship from the US indicates close ties between conservative political ideology and COVID-19 scepticism (Latkin et al., 2021). Motta et al. (2020) showed how COVID-19 misinformation shared by right-leaning media outlets such as Fox News and Breitbart have contributed to the spread of misinformation about the virus. Subsequently, this increased the likelihood that media users perceived COVID-19's health risks to be exaggerated. However, COVID-19 denial does not appear to be linked to mainstream right-wing attitudes in Germany (Reinemann et al., 2020). Instead, in Europe, COVID-19 scepticism has been associated with right-wing populist or extremist parties such as the Alternative for Germany (AfD) and the Austrian Freedom Party (FPÖ) (Eberl et al., 2021; Reuband, 2021). Media reports highlighting the participation of rightwing extremist individuals at the Anti-Corona rallies in Germany also point towards a link between COVID-19 scepticism and far-right attitudes (e.g., DW, 2021a). Such a link also seems plausible since views typically associated with the broader spectrum of right-wing extremist attitudes, e.g., Social Darwinism ${ }^{2}$ and anti-Semitism, gained prominence during the pandemic. With regard to political ideology, we thus hypothesise:

- H2: The more individuals share far-right attitudes, the more likely they are to endorse COVID-19 scepticism.

\footnotetext{
${ }^{2}$ Examples are, e.g., cost-benefit calculations that were made to weigh the economic consequences of the protective measures against the protection of risk groups (Löhr, 2020).
} 


\section{Conspiracy beliefs}

Conspiracy theories are more likely to emerge during societal crises (van Prooijen \& Douglas, 2017). Research suggests that people feel the need to explain events with severe consequences (Douglas et al., 2017; Leman \& Cinnirella, 2007). And, indeed, COVID-19 related conspiracy beliefs, which emerged shortly after the first news of COVID-19, are relatively widespread among the general public (e.g., Uscinscki, 2020). Several anti-Semitic conspiracy theories emerged around the globe, blaming Jews such as George Soros for the outbreak of the pandemic (see e.g., Gerstenfeld, 2020 for a short overview). ${ }^{3}$ Other popular conspiracy theories focus on the origins of the pandemic (e.g., Banai et al., 2020; Imhoff \& Lamberty, 2020). Conspiracy beliefs have been identified as a crucial driver of various forms of science scepticism (e.g., Rutjens \& van der Lee, 2020; Lewandowsky et al., 2013). A study by Rothmund et al. (2020) confirms this pattern for COVID-19 scepticism showing that individuals who deny the seriousness of the COVID-19 pandemic are more likely to believe in conspiracy theories. Also, scholarship on the impact of conspiracy beliefs on health behaviour in the COVID-19 pandemic points to such a relationship (e.g., Banai et al., 2020; Imhoff \& Lamberty, 2020). Therefore, hypothesis 3 reads as:

- H3: The more individuals believe in conspiracy theories, the more likely they are to endorse COVID-19 sceptical views.

\section{Political trust}

Furthermore, we expect that (dis)trust in political institutions is a predictor for COVID-19 sceptic attitudes. Political trust is seen as central to the functioning of democratic systems; it reduces transaction costs, and removes the need to justify every decision made (Braithwaite \&

\footnotetext{
${ }^{3}$ Moreover, a yellow star with the word 'unvaccinated' mimicking the 'Jewish star' gained prominence among anti-COVID protesters and anti-vaxxers in Germany (DW, 2021b).
} 
Levi, 1998). Recent studies reveal that those who mistrust political institutions are also more sceptical of public-health measures during a crisis (see e.g., Plohl \& Musil, 2020; Tsai et al., 2020). Furthermore, COVID-19 sceptics are also less likely to trust COVID-19 experts, the WHO (Rutjens et al., 2021), scientists (Rothmund et al., 2020), traditional media, and the government (Reinemann et al., 2020). Based on these studies, our hypothesis reads as:

- H4: The more individuals trust in political institutions, the less likely they hold COVIDsceptic attitudes.

\section{Research Design and Methodology}

We empirically analyse the drivers for COVID-19 scepticism based on a representative survey of citizens conducted in September and October 2020 in the Eastern German state of Thuringia. Thuringia presents an interesting case to investigate COVID-sceptical attitudes: as a result of negative net migration to West Germany, Thuringia has the second-highest average age in Germany (see Statista, 2021). Since an ageing population is prone to a higher risk of hospitalisation and death by the coronavirus (Fisman et al., 2020; Kremer \& Thurner, 2020), risk perception in Thuringia might be comparably high. However, at the same time, the number of infections in Thuringia prior to the survey period has been very low compared to other regions in Germany ${ }^{4}$, which might result in lower levels of risk perception. Regarding ideology, the radical right-wing populist party AfD is very successful in Thuringia (Weisskircher, 2020), and the number of citizens holding far-right views is comparatively high (Reiser et al., 2021; Decker et al., 2020), which might drive COVID-19 scepticism.

Despite the overall broad acceptance of the lockdown measures to mitigate the pandemic, there have been numerous protests in Germany and also in Thuringia directed against these measures (Reiser et al., 2021). The participants of these protests have been heterogeneous:

\footnotetext{
${ }^{4}$ This, however, changed after the survey had been conducted since Thuringia has been hit severely during the second and third wave of the pandemic (RKI, 2020); see figure S.1 in the supplementary materials.
} 
next to groups severely affected by the measures, they were organised by the anti-lockdown group 'Querdenken' ('Lateral Thinking',) and partly organised or infiltrated by right-wing extremists (De Weck 2020).

\section{Design of the Survey}

The analysis is based on a representative survey (Schmitt et al., in press) conducted between 3. September and 5. October 2020 via telephone interviews (CATI). The sample consists of 1,110 citizens of the East German state of Thuringia who are at least 18 years and eligible to vote at federal elections. The sampling frame was obtained via RDD (random-digit dialling), and in multi-member households, the last birthday method was applied (Reiser et al., 2021). The survey data was weighted by age, gender, education and household size (for information on the sample, see table 4 in the appendix).

\section{Operationalisation and Measurement}

\section{Dependent variable}

COVID-19 scepticism was measured based on the item 'The virus is actually not worse than the flu'. Participants indicated on a four-point-scale whether they 'fully agree', 'mostly agree', 'mostly disagree' or 'fully disagree' with the statement. Respondents who chose to answer the 'Don't know' category $(\mathrm{N}=9)$ were excluded from the analysis. For the logistic regression analysis, responses were recoded into a dummy variable ('mostly disagree'/'fully disagree' = 0 ; 'mostly agree'/'fully agree' $=1) .^{5}$

\footnotetext{
${ }^{5}$ As a robustness check, we also computed a COVID-19 scepticism index consisting of three items. Next to the item mentioned beforehand the two additional items are 'The danger posed by the coronavirus is greatly exaggerated by the media' and 'I trust my feelings about dealing with Corona more than so-called experts' (see Rees et al., 2020). A OLS regression model using this additive index as dependent variable provided similar results
} 


\section{Explanatory variables}

Risk perception for their own health due to the coronavirus was measured by asking the respondents: 'How high do you rate the risk of the Corona crisis for your own health?'. Respondents had to answer on a five-point-scale ranging from 'no risk' to 'very high risk'. Responses were recoded into a dummy variable with 'low risk' (0 for 'no risk', 'very low risk' and 'low risk') and 'high risk' (1 for 'high risk' and 'very high risk').

Risk perception for their individual economic situation by the COVID-19 crisis was measured based on the question: 'How high do you rate the risk of the Corona crisis for your personal economic situation?' The responses on a five-point-scale ranging were recoded into a dummy variable: 'low risk' ('no risk', 'very low risk', 'low risk') = 0; 'high risk' ('high risk', 'very high risk') $=1 .^{6}$

Political ideology of the respondents was operationalised as far-right attitudes. ${ }^{7}$ We rely on a definition widely used in other studies in the German context (e.g., Decker et al., 2020; Zick \& Küpper 2021): right-wing extremism is defined as a multidimensional pattern of attitudes which are linked by the ideas of inequality and refer to the dimensions of ethnocentrism and Neo-Nazi ideology (see also Salomo, 2019, p. 107). Right-wing extremist attitudes are captured based on ten single items (see appendix for the items) that are combined into a right-wing extremism mean scale.

to our full logistic regression model presented in the text. Likewise, a logistic regression model using a dummy variable computed of the three items where an individual was coded as COVID-19 sceptic (=1), when (s)he responded 'fully agree' or 'mostly agree' on all three items generated similar results. The only difference is that our control variable 'political interest' is not significant; see supplementary material tables S.1-S.2.

${ }^{6}$ Explorative models including economic affectedness instead of economic risk perception showed similar findings (see table S.5 in the supplementary material).

${ }^{7}$ Political ideology can also be measured by self-placement on a left-right scale or party identification. We present the models using these alternative operationalisations in the supplementary materials (table S.3). General political ideology was operationalised as self-placement on the left-right scale ranging from 1 ('very far left') to 7 ('very far right') and is included as a continuous variable in the analysis. To assess party identification, we asked: 'Generally speaking, do you tend towards a particular party? If yes, towards which one?'. The Social Democratic Party (SPD) was used as a reference category. Both measurements fail to significantly predict COVID-sceptic attitudes. 
Conspiracy belief related to the COVID-19 pandemic was captured by the item 'There are secret organisations that have a great influence on political decisions during the Corona crisis' (see Rees et al., 2020). Participants rated the item on a four-point scale ranging from 'fully agree' to 'fully disagree'. Responses were recoded into a dummy variable ('mostly disagree'/'fully disagree' $=0$; 'mostly agree'/'fully agree' $=1$ ).

We measured trust in three institutions that are crucial for the mitigation of the pandemic, as well as the spread of information on the coronavirus and recommended health behaviours: the federal government, the media and the Robert Koch Institute (RKI). The RKI is the federal agency and research institute that monitors public health and is responsible for the control and prevention of diseases in Germany. Thus, it is continuously estimating the risk for the population, and is one of the main sources of information for the government and the public during the COVID-19 pandemic. Participant indicated their level of trust with each of these institution on a five-point-scale ranging from 'trust it fully' to 'not trust it at all'. For the analysis, responses were recoded into three groups: those with 'high trust' ('trust it fully', 'trust it largely'), with 'partial trust' ('partially trust it') and 'no/low trust' ('rather not trust it', 'not trust it at all'). ${ }^{8}$

In the multivariate analyses, we further included control variables for age, gender, education and political interest. Furthermore, we asked participants whether their health had been affected by the coronavirus, or whether they had close friends, family or relatives that had been affected, and whether they belonged to a risk group. See appendix for descriptive statistics for the control variables. To test our hypotheses, we present logistic regression analysis.

\footnotetext{
${ }^{8}$ We also tested a model based on an alternative operationalisation (five-point scale instead of a dummy variable) of threat to own health, threat to personal economic situation, and the three trust measurements. None of these alternative specifications changed our general conclusion that far-right attitudes, as well as trust in the government and public health authorities are central predictors of COVID-19 scepticism (see table S.4 in the supplementary material).
} 


\section{Results}

\section{Descriptive Results}

The descriptive analysis reveals that 35 per cent of the respondents share the view that 'the virus is not worse than the flu' (15 per cent agreed 'mostly' and 20 per cent agreed 'fully'). However, the majority of the respondents does not have COVID-19 sceptical views since 43 per cent of Thuringians disagreed vehemently ('completely disagree') and another 22 per cent mostly disagreed. Our data show that the group of Corona sceptics is politically heterogeneous. Respondents locate themselves from the far-left (19 per cent) to the far-right (47 per cent) on the political left-right axis. However, the sceptical view is more widespread on the right side of the political spectrum (see also figure S.2 in the supplementary material). Corresponding with this, there is also an overlap between far-right and COVID-19 sceptic attitudes (see table 1): Of the respondents with far-right attitudes, almost two thirds are COVID-19 sceptics (compared to 27 per cent of those not having far-right attitudes). Of the COVID-19 sceptics, about a third have right-wing extremist attitudes (compared to nine per cent of the non-sceptics). While the vast majority of Corona sceptics in Thuringia does not have far-right attitudes, the majority of those surveyed who share right-wing extremist attitudes also endorse COVID-19 scepticism. In addition, COVID-19 scepticism overlaps with COVID-related conspiracy belief since more than half of the respondents (53 per cent per cent) who endorse COVID-related conspiracy theories also share COVID-19 sceptic attitudes.

The descriptive analysis also points towards a relationship between political trust and Corona scepticism. COVID-19 sceptics report a significant lower share of trust in the political institutions than non-sceptics: only 25 per cent report high trust in the government (compared to 53 per cent among the non-sceptics), 17 per cent in the traditional media (30 per cent among the non-sceptics), and 52 per cent in public health authorities (83 per cent among the nonsceptics). 
Table 1. Right-wing extremism, COVID-related conspiracy belief, and Corona-scepticism

\begin{tabular}{|llc|c|}
\hline & & Corona-scepticism ('The virus is actually not worse than \\
& & \multicolumn{2}{c|}{$\begin{array}{c}\text { Agree } \\
\text { the flu') }\end{array}$} \\
\hline Right-wing extremist & no & $60,2 \%$ & $22,5 \%$ \\
attitudes & yes & $6,2 \%$ & $11,1 \%$ \\
\hline COVID-related conspiracy & no & $52.9 \%$ & $17.2 \%$ \\
belief & yes & $14.1 \%$ & $15.8 \%$ \\
\hline
\end{tabular}

\section{Results of the Logistic Regression Analysis}

To evaluate our theoretical expectations about the drivers of COVID-19 scepticism, table 2 presents the results of the logistic regression models. As can be seen from the models 1 and 5 in table 2, risk perception with regard to one's own health has a significant effect on COVID19 sceptic attitudes. Those respondents who perceive the pandemic as a threat to their own health are less likely to share COVID-19 sceptic attitudes, thus confirming H1a. In contrast, viewing the pandemic as an economic threat is positively associated with COVID-19 scepticism (see model 1 in table 2). This means that individuals who perceive the pandemic as a risk for their own economic situation are more likely to have COVID-19 sceptic attitudes. While this is in line with the theoretical expectation, however, economic risk perception is no significant predictor in the full model (model 5, table 2). Therefore, we cannot confirm H1b.

Regarding political ideology, our multivariate analysis reveals that far-right attitudes are a strong predictor of Corona sceptic attitudes (see models 2 and 5 in table 2). To get a substantive understanding of the significant effects, figure 1 presents the predicted probabilities. It shows that individuals who have far-right attitudes are more likely to share Corona sceptic attitudes, confirming our hypothesis 2 .

Pandemic-related conspiracy belief is also significantly associated with COVID-19 scepticism see model 3 in table 2), and - in line with H3 - this relationship remains significant in the full model (see model 5 in table 2).

We also find support for our theoretical argument that mistrust in political institutions drives COVID-19 scepticism. Model 4 and model 5 (see table 2) show that the level of trust in 
the government and the public health authority RKI significantly predicts COVID-19 scepticism: high trust in the federal government as well as showing a medium and high level of trust towards public health experts impedes COVID-19 scepticism (see also the predicted probabilities in figure 1 . However, in contrast to our expectation in $\mathrm{H} 4$, we do not find a significant link between trust in traditional media and COVID-19 scepticism.

Looking briefly at the control variables, the analyses show no significant effect of the socio-demographic variables (age, gender, education level) (see model 5 in table 2). Thus, in contrast to other studies (e.g., Latkin et al., 2021; Rothmund et al., 2020), younger people are not more likely to share COVID-19 sceptic attitudes. Furthermore, the affectedness by the virus does not significantly influence the likelihood to endorse COVID-19 scepticism. Hence, in contrast to the study of Dryhurst et al. (2020, p. 998), our results suggest that it is less the direct personal experience with the virus but rather the risk perception for its own health which impacts sceptic attitudes. Finally, self-reported political interest impedes scepticism.

Figure 1. Predicted Probabilities for COVID-19 Scepticism.

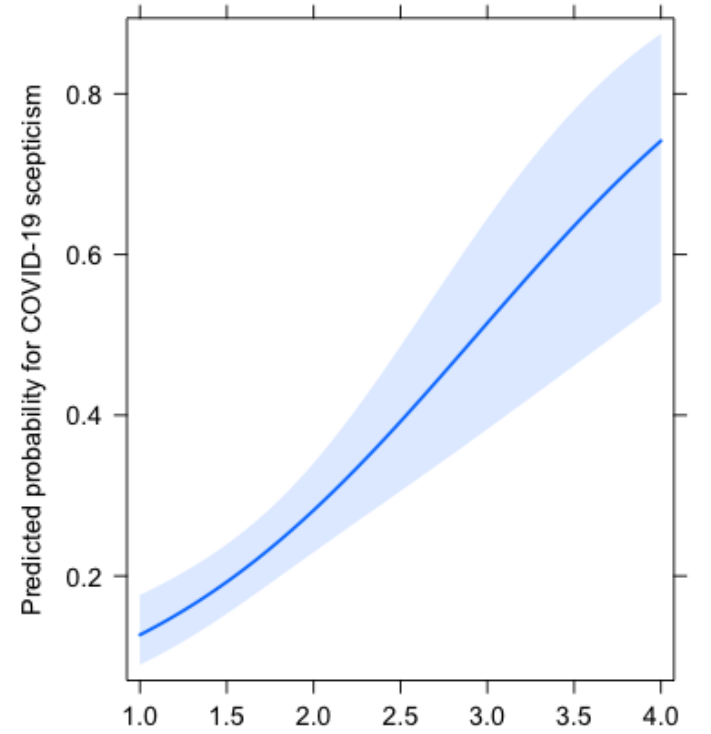

Right-wing extremism (mean scale; 1 = not extremist | 4 = extremist)

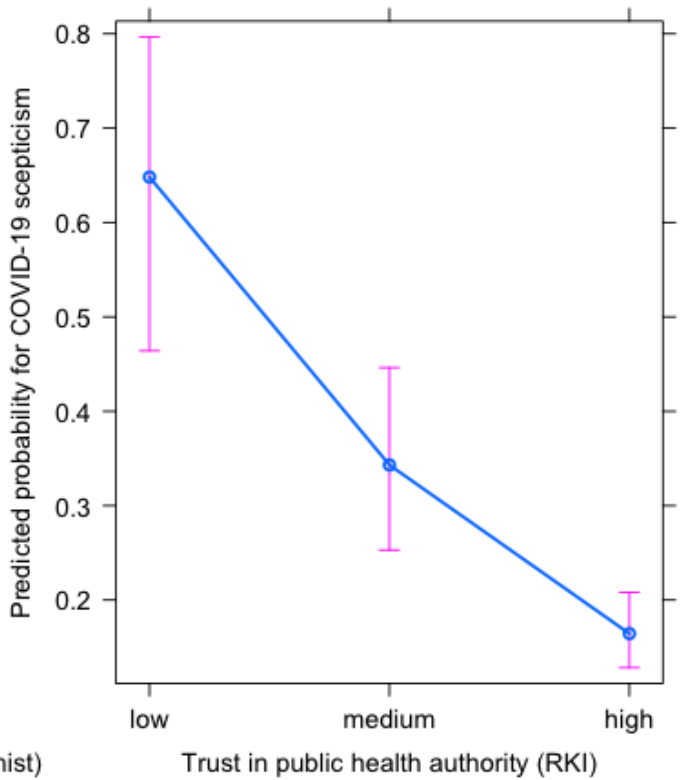

Note: Based on model 5 in table 2. 
Table 2. Logistic Regression Models (odds ratios, 95\% confidence intervals)

\begin{tabular}{|c|c|c|c|c|c|}
\hline \multicolumn{6}{|c|}{ Dependent variable: dummy COVID-19 scepticism ('the virus is actually not worse than the flu') } \\
\hline & Model (1) & Model (2) & Model (3) & Model (4) & Model (5) \\
\hline & Risk perception & Political ideology & Conspiracy belief & Trust & Full model \\
\hline Risk perception (health) & $0.345^{* * * *}$ & & & & $0.518^{* *}$ \\
\hline (high risk) & {$[0.238 ; 0.491]$} & & & & {$[0.321 ; 0.822]$} \\
\hline Risk perception (pers. & $1.754 * *$ & & & & 0.840886 \\
\hline econ. situation) (high risk) & {$[1.215 ; 2.535]$} & & & & {$[0.498 ; 1.404]$} \\
\hline Far-right attitudes & & $3.837 * * *$ & & & $2.704 * * *$ \\
\hline & & {$[2.953 ; 5.038]$} & & & {$[1.858 ; 3.972]$} \\
\hline Conspiracy belief & & & $3.533 * * *$ & & $2.039 * *$ \\
\hline & & & {$[2.551 ; 4.915]$} & & {$[1.328 ; 3.132]$} \\
\hline Trust federal government & & & & 0.906 & 0.827 \\
\hline (medium) & & & & {$[0.590 ; 1.394]$} & {$[0.489 ; 1.400]$} \\
\hline Trust federal government & & & & $0.441 * * *$ & $0.500^{*}$ \\
\hline (high) & & & & {$[0.276 ; 0.711]$} & {$[0.279 ; 0.900]$} \\
\hline Trust media (medium) & & & & 0.931843 & 0.868 \\
\hline & & & & {$[0.633 ; 1.374]$} & {$[0.534 ; 1.413]$} \\
\hline Trust media (high) & & & & 1.172 & 1.629 \\
\hline & & & & {$[0.743 ; 1.852]$} & {$[0.941 ; 2.842]$} \\
\hline Trust Robert Koch & & & & $0.173 * * *$ & $0.284 * *$ \\
\hline Institute (medium) & & & & {$[0.083 ; 0.341]$} & {$[0.121 ; 0.626]$} \\
\hline Trust Robert Koch & & & & $0.071 * * *$ & $0.107 * * *$ \\
\hline Institute (high) & & & & {$[0.035 ; 0.136]$} & {$[0.047 ; 0.225]$} \\
\hline Age & 0.997 & $0.987 * *$ & 1.000 & 1.008 & 0.996 \\
\hline & {$[0.989 ; 1.006]$} & {$[0.978 ; 0.996]$} & {$[0.991 ; 1.009]$} & {$[0.992 ; 1.010]$} & {$[0.985 ; 1.008]$} \\
\hline Gender (female) & 0.975 & 0.980 & 0.811 & 0.92 & 0.968 \\
\hline & {$[0.737 ; 1.291]$} & {$[0.720 ; 1.333]$} & {$[0.590 ; 1.111]$} & {$[0.680 ; 1.251]$} & {$[0.661 ; 1.416]$} \\
\hline Education (A-levels or & $0.553 * *$ & 0.833 & $0.66584 *$ & $0.678 *$ & 0.973 \\
\hline higher) & {$[0.385 ; 0.785]$} & {$[0.568 ; 1.212]$} & {$[0.449 ; 0.977]$} & {$[0.461 ; 0.990]$} & {$[0.6113 ; 1.541]$} \\
\hline Political interest & $0.729 * * *$ & $0.839 *$ & $0.700 * * *$ & $0.691 * * *$ & $0.773 * *$ \\
\hline & {$[0.636 ; 0.834]$} & {$[0.721 ; 0.975]$} & {$[0.600 ; 0.813]$} & {$[0.594 ; 0.801]$} & {$[0.638 ; 0.933]$} \\
\hline Affectedness by COVID- & $1.67984 *$ & 1.352 & $1.810^{*}$ & $2.656 * * *$ & 1.302 \\
\hline 19 (no) & {$[1.064 ; 2.712]$} & {$[0.840 ; 2.222]$} & {$[1.091 ; 3.091]$} & {$[1.565 ; 4.667]$} & {$[0.688 ; 2.548]$} \\
\hline Affectedness by COVID- & 1.508 & 0.8725 & 1.062 & 1.752 & 0.777 \\
\hline 19 (no, but risk group) & {$[0.854 ; 2.696]$} & {$[0.469 ; 1.633]$} & {$[0.556 ; 2.047]$} & {$[0.921 ; 3.403]$} & {$[0.343 ; 1.780]$} \\
\hline Intercept & 1.418 & $0.115^{* * *}$ & 0.771 & $10.865 * * *$ & 1.339 \\
\hline & {$[0.675 ; 2.970]$} & {$[0.046 ; 0.283]$} & {$[0.348 ; 1.690]$} & {$[4.118 ; 29.895]$} & {$[0.319 ; 5.726]$} \\
\hline Observations & 1,008 & 960 & 879 & 988 & 811 \\
\hline Log Likelihood & -538.547 & -450.854 & -435.727 & -471.373 & -317.184 \\
\hline AIC & $1,095.093$ & 917.708 & 887.455 & 968.746 & 668.368 \\
\hline Nagelkerke Pseudo-R2 & 0.115 & 0.203 & 0.148 & 0.251 & 0.363 \\
\hline
\end{tabular}




\section{Conclusion}

During the COVID-19 pandemic, many societies have additionally been challenged by COVID-19 sceptics who downplay or deny the seriousness of the illness. It is crucial to understand the drivers of these COVID-19 sceptical attitudes: they endanger the successful containment of the pandemic since they result in lower acceptance and willingness to adhere to the mitigation measures (Plohl \& Musil 2021). Furthermore, as different forms of science scepticism have increased during the last years and challenge societies and democracies, it is important to understand the factors fuelling COVID-related scepticism as one specific form of science scepticism (e.g., Dryhurst et al., 2020; Rutjens et al., 2020). Using a representative sample of citizens from the East German region of Thuringia, our analysis shows that about a third of the respondents shared COVID-19 sceptic attitudes. The share is significantly higher than the results for the US (20 per cent), UK (17 per cent), and Canada (12 per cent) based on a similar measurement ('the seasonal flu is just as dangerous as the coronavirus') (Pennycook, 2020; see also Latkin et al., 2021). Further studies are needed to examine why Thuringians show this comparably high level of sceptical attitudes. One possible explanation might be that in contrast to other regions in Germany and other countries (e.g., Italy, Spain), Thuringia was hardly hit by the pandemic in the first wave and only 12 per cent of the respondents had a personal experience with the virus (see Reiser et al., 2021; see also table 4 in the appendix). This might explain the higher share of respondents who denied or downplayed the virus. To further understand these differences and dynamics, it would be important to analyse the patterns of COVID-19 scepticism over time.

Regarding the drivers of scepticisms, risk perception with regard to one's health decreases the likelihood of COVID-19 sceptic attitudes. This confirms our hypothesis 1a and findings from other studies, which also show such a link (e.g., Latkin et al., 2021). It is interesting to note that in contrast to the result of Dryhurst et al. (2020), the affectedness by the 
virus - either personally or in the family - does not significantly influence the likelihood to endorse COVID-19 scepticism. Hence, our result suggests that it is less the direct personal experience with the virus but rather the risk perception for one's health that impacts sceptic attitudes. Interestingly, in contrast to our expectation (H1b), our study reveals that risk perception for one's economic situation does not significantly influence COVID-19 sceptical attitudes. That means that individuals who see a threat for their own economic situation are not more prone to deny the danger of the virus than those not having this fear. While research shows that economic risk perception increases the likelihood to deny man-made climate change (Lejano \& Dodge, 2017; Rutjens et al., 2021), this pattern cannot be observed for COVID-19 scepticism. This result points to differences between COVID-19 scepticism and climate change scepticism.

With regard to political ideology, our study confirms hypothesis 2 by showing a strong significant effect of far-right attitudes on COVID-19 sceptical attitudes. This reinforces findings that point to differences regarding ideology between the US and Europe: while there is a relationship between mainstream right-wing views (political conservatism) and COVID-19 scepticism in the US, in Europe, scepticism is associated with radical right-wing views (see also Rutjens et al., 2021; Latkin et al., 2020; Rothmund et al., 2020). By that, COVID-19 scepticism seems to mirror climate change scepticism (Kulin et al., 2021; Jylhä et al., 2020; Krange et al., 2019).

Concerning hypothesis 3 , our study confirms earlier findings indicating a link between COVID-19 scepticism and COVID-related conspiracy theories (Rothmund et., 2020). By that, our empirical result speaks to the literature on science scepticism, where conspiracy beliefs have been identified as a crucial driver of various forms of science scepticism (e.g., Rutjens \& van der Lee, 2020; Hornsey et al., 2018; Lewandowsky et al., 2013).

In line with hypothesis 4, our study shows that low trust in the government and public health authorities drives COVID-19 scepticism. Thus, our results are consistent with previous 
scholarship showing a link between trust and COVID-19 scepticism (Pennycook et al., 2020; Rothmund et al., 2020). However, in contrast to other studies (e.g., Reinemann et al., 2020), we do not find a significant link between trust in traditional media and COVID-19 scepticism.

Thus, this study reveals important drivers for COVID-19 scepticism. However, building on conceptual work on climate change scepticism (see 2), we proposed to distinguish three types of COVID-19 scepticism. While our study only refers to the type of impact sceptics, further research should broaden the perspective by including trend and attribution sceptics to capture and understand all three dimensions of COVID-19 scepticism. In addition, further studies should focus more closely on the mechanisms of how these factors increase COVID-19 scepticism. This would also allow developing counterstrategies against COVID-19 scepticism and other forms of health-related scepticism.

The strong impact of mistrust in political institutions points to deeper roots of sceptic attitudes. It has been assumed that low trust in institutions also is a driver for other forms of science scepticism, such as climate change denial (Hornsey et al. 2016) and vaccine hesitancy (Rozek et al., 2021). Thus, one could argue that science scepticism in general appears to be fed by perceived representational deficits and a feeling of a lack of political efficacy. Further research should investigate these potential causal mechanisms since sceptics might limit progress in the mitigation of societal problems, e.g., on the route to carbon neutrality or achieving herd immunity to contain the COVID-19 pandemic - and might be a challenge for representative democracy.

\section{Disclosure Statement}

No potential conflict of interest was reported by the author. 


\section{Funding}

The study was funded by the Thuringian State Chancellery.

\section{References}

Allcott, H., Boxell, L., Conway, J., Gentzkow, M., Thaler, M. \& Yang, D. (2020).

Polarization and public health: Partisan differences in social distancing during the coronavirus pandemic. Journal of Public Economics, 191, 1-11. https://doi.org/10.1016/j.jpubeco.2020.104254

Banai, I., P., Banai, B. \& Mikloušić, I. (2021). Beliefs in COVID-19 conspiracy theories, compliance with the preventive measures, and trust in government medical officials. Current Psychology. https://doi.org/10.31234/osf.io/yevq7

Braithwaite, V. \& Levi, M. (Eds.) (1998). Trust and Governance. Sage.

Bruder, M. \& Kunert, L. (2021), The conspiracy hoax? Testing key hypotheses about the correlates of generic beliefs in conspiracy theories during the COVID-19 pandemic. International Journal of Psychology. Advance online publication. http://dx.doi.org/10.23668/psycharchives.3158

De Weck, J. (2020, September 23). Germany’s Lateral Thinkers, Unite. Foreign Policy. https://foreignpolicy.com/2020/09/23/germanys-lateral-thinkers-unite/

Decker, O., Kiess, J., Schuler, J., Handke, B., Pickel, G. \& Brähler, E. (2020). Die Leipziger Autoritarismus Studie 2020: Methode, Ergebnisse und Langzeitverlauf. In O. Decker \& E. Brähler (Eds), Autoritäre Dynamiken: Neue Radikalität-alte Ressentiments (pp. 27-87). Psychosozial-Verlag.

DW (2021a, April 3). Meet Germany's 'Querdenker' COVID protest movement. https://www.dw.com/en/meet-germanys-querdenker-covid-protest-movement/a$\underline{57049985}$

DW (2021b, May 5). Ban mock Jewish star at COVID protests, German anti-Semitism czar urges. https://www.dw.com/en/ban-mock-jewish-star-at-covid-protests-german-anti$\underline{\text { semitism-czar-urges/a-57467261 }}$

DW (2021c, May 11). Germany: Politicians worry about radicalization at anti-lockdown protests. https://www.dw.com/en/germany-politicians-worry-about-radicalization-atanti-lockdown-protests/a-53388404 
Douglas, K. M., Sutton, R. M. \& Cichocka, A. (2017). The Psychology of Conspiracy

Theories. Current Directions in Psychological Science, 26(6), 538-542. https://doi.org/10.1177\%2F0963721417718261

Dryhurst, S., Schneider, C. R., Kerr, J., Freeman, A. L. J., Recchia, G. \& van der Bles, A. M. (2020). Risk perception of COVID-19 around the world. Journal of Risk Research, 23(7-8), 994-1006. https://doi.org/10.1080/13669877.2020.1758193

Eberl, J., Huber, R. A., \& Greussing, E. (2021). From populism to the 'plandemic': Why populists believe in COVID-19 conspiracies. Journal of elections, Public Opinion and Parties, 31(1), 272-284. doi:10.1080/17457289.2021.1924730

Fisman, D. N., Greer, A. L. \& Ashleigh, R. T. (2020). Age Is Just a Number: A Critically Important Number for COVID-19 Case Fatality. Annals of Internal Medicine, 173(9), 762-764. https://doi.org/10.7326/M20-4048

Fuchs-Schündeln, N., Kuhn, M. \& Tertilt, M. (2020). The Short-Run Macro Implications of School and Child-Care Closures,' ECONtribute Discussion Papers Series 002.

Gerstenfeld, M. (2020). The COVID-19 Crisis: Impact and Implications. Begin-Sadat Center for Strategic Studies. Retrieved June 23, 2021, from http://www.jstor.org/stable/resrep26356.12

Carnegie Endowment (2021). Global Protest Tracker. https://carnegieendowment.org/publications/interactive/protest-tracker

Gollwitzer, A., Martel, C., Brady, W. J., Pärnamets, P., Freedman, I. G., Knowles, E. D. \& Van Bavel, J. J. (2020). Partisan differences in physical distancing are linked to health outcomes during the COVID-19 pandemic. Nature Human Behaviour 4(11), 11861197. https://doi.org/10.1038/s41562-020-00977-7

Hornsey, M. J., Harris, E. A. \& Fielding, K. S. (2018). Relationships among conspiratorial beliefs, conservatism and climate scepticism across nations. Nature Climate Change, 8(7), 614-620. https://doi.org/10.1038/s41558-018-0157-2

Hornsey, M. J., Harris, E. A., Bain, P. G., \& Fielding, K. S. (2016). Meta-analyses of the determinants and outcomes of belief in climate change. Nature Climate Change, 6(6), 622-626. https://doi.org/10.1038/nclimate2943

Imhoff, R. \& Lamberty, P. (2020), A Bioweapon or a Hoax? The Link BetweenDistinct Conspiracy Beliefs Aboutthe Coronavirus Disease (COVID-19) Outbreak and Pandemic Behavior. Social Psychology and Personality Science, 11(8), 1110-1118. 
Jylhä, K., P. Strimling, \& Rydgren, J. (2020). Climate Change Denial among Radical RightWing Supporters. Sustainability, 12(23), 10226-10240. https://doi.org/10.3390/su122310226

Krange, O., Kaltenborn, B. P., \& Hultman, M. (2019). Cool dudes in Norway: Climate change denial among conservative Norwegian men. Environmental Sociology, 5(1), 1-11. https://doi.org/10.1080/23251042.2018.1488516

Kremer, H.-J., Thurner, W. (2020). Age Dependence in COVID-19 Mortality in Germany. Deutsches Ärzteblatt International, 117(25), 432-433. https://doi.org/10.3238/arztebl.2020.0432

Krings, V. C., Steeden, B., Abrams, D. \& Hogg, M. A. (2021). Social attitudes and behavior in the COVID-19 pandemic: Evidence and prospects from research on group processes and intergroup relations. Group Processes \& Intergroup Relations, 24(2), 195-200. https://doi.org/10.1177\%2F1368430220986673

Kulin, J., Johansson Sevä, I., \& Dunlap, R. E. (2021). Nationalist ideology, rightwing populism, and public views about climate change in Europe. Environmental Politics, Advance online publication. 1-24. https://doi.org/10.1080/09644016.2021.1898879

Lange, M. \& Monscheuer, O. (2021). Spreading the Disease: Protest in Times of Pandemics, ZEW Discussion Paper No. 21-009. https://www.zew.de/publikationen/spreading-thedisease-protest-in-times-of-pandemics

Latkin, C. A., Dayton, L., Moran, M., Strickland, J. C., \& Collins, K. (2021). Behavioral and psychosocial factors associated with COVID-19 skepticism in the United States. Current Psychology. Advance online publication, 1-9. https://doi.org/10.1007/s12144$\underline{020-01211-3}$

Lejano, R.P. \& Dodge, J. (2017). The narrative properties of ideology: The adversarial turn and climate skepticism in the USA. Policy Science, 50(2), 195-215. https://doi.org/10.1007/s11077-016-9274-9

Leman, P.J. \& Cinnirella, M. (2007). A major event has a major cause: Evidence for the role of heuristics in reasoning about conspiracy theories. Social Psychological Review, 9(2), 18-28.

Lewandowsky S., Gignac G. E., Oberauer K. (2013). The Role of Conspiracist Ideation and Worldviews in Predicting Rejection of Science. PLOS ONE, 10(8), 1-11. https://doi.org/10.1371/journal.pone.0075637 
Löhr, J. (2020, March 3). Corona-Moral: Geld oder Leben? Frankfurter Allgemeine Zeitung. https://www.faz.net/aktuell/wirtschaft/unternehmen/warum-eine-rezession-schlimmersein-kann-als-das-coronavirus-16696572.html

McKee, M. \& Stuckler, D. (2020). If the world fails to protect the economy, COVID-19 will damage health not just now but also in the future. Nature Medicine, 26, 640-642. https://doi.org/10.1038/s41591-020-0863-y

Motta, M., Stecula, D., \& Farhart, C. (2020). How Right-Leaning Media Coverage of COVID-19 Facilitated the Spread of Misinformation in the Early Stages of the Pandemic in the U.S. Canadian Journal of Political Science, 53(2), 335-342. https://doi.org/10.1017/S0008423920000396

Naumann, E., Möhring, K., Reifenscheid, M., Wenz, A., Rettig, T., Lehrer, R., Krieger, U., Juhl, S., Friedel, S., Fikel, M., Cornesse, C. \& Blom, A. G. (2020). COVID-19 policies in Germany and their social, political, and psychological consequences. European Policy Analysis, 6(2), 191-202. https://doi.org/10.1002/epa2.1091

Packer, D. J., Ungson, N. D. \& Marsh, J. K. (2021). Conformity and reactions to deviance in the time of COVID-19. Group Processes and Intergroup Relations, 24(2), 311-317. DOI: $10.1177 / 1368430220981419$

Pennycook, G., McPhetres, J., Bago, B. \& Rand, D. G. (2021). Beliefs about COVID-19 in Canada, the U.K., and the U.S.A.: A novel test of political polarization and motivated reasoning. Advance online publication. https://doi.org/10.31234/osf.io/zhjkp

Plohl, N. \& Musil, B. (2021). Modeling compliance with COVID-19 prevention guidelines: the critical role of trust in science. Psychology, Health \& Medicine, 26(1), 1-12. https://doi.org/10.1080/13548506.2020.1772988

Rahmstorf, S. (2004). The climate sceptics. Potsdam Institute for Climate Impact Research. http://www.pikpotsdam.de/ stefan/Publications/Other/rahmstorf_climate_sceptics_2004.pdf

Rees, J., Papendick, M., Rees, Y., Wäschle, F., \& Zick, A. (2020). Erste Ergebnisse einer Online-Umfrage zur gesellschaftlichen Wahrnehmung des Umgangs mit der CoronaPandemie in Deutschland (Forschungsbericht IKG). Bielefeld: Institut für interdisziplinäre Konflikt- und Gewaltforschung (IKG).

Reinemann, C., Haas, A., \& Rieger, D. (2021). 'I don't care, 'cause I don't trust them!' The Impact of Information Sources, Institutional Trust and Populist Attitudes on the Perception of the COVID-19 Pandemic During the First Lockdown in Germany. Paper 
presented at the 71st Annual Conference of the ICA, Virtual Conference. http://dx.doi.org/10.13140/RG.2.2.14563.99360

Reiser, M., Küppers, A., Hebenstreit, J., Salheiser, A. \& Vogel, L. (2021). THÜRINGEN MONITOR: Die Corona-Pandemie in Thüringen. https://www.landesregierungthueringen.de/fileadmin/user_upload/Landesregierung/Landesregierung/Thueringenm onitor/Thu_ringen_Monitor_bf_2020.pdf

Reuband, K.-H. (2021). Regionale AfD-Milieus und die Dynamik der Corona-Ausbreitung Eine Analyse auf der Basis kreisfreier Städte und Landkreise in Sachsen. Zeitschrift für Parteiwissenschaften, 27(1), 1-14.

Rothmund, T., Farkhari, F., Azevedo, F., \& Ziemer, C. (2020). Scientific Trust, Risk Assessment, and Conspiracy Beliefs about COVID-19 - Four Patterns of Consensus and Disagreement between Scientific Experts and the German Public. Advance online publication. https://doi.org/10.31234/osf.io/4nzuy

Rozek L., Jones P., Menon A., Hicken A., Apsley S. \& King E. (2021). Understanding Vaccine Hesitancy in the Context of COVID-19: The Role of Trust and Confidence in a Seventeen-Country Survey. International Journal of Public Health. Advance online publication. https://doi.org/10.3389/ijph.2021.636255

Rutjens, B. T. \& van der Lee, R. (2020). Spiritual skepticism? Heterogeneous science skepticism in the Netherlands. Public Understanding of Science, 29(3), 335-352. https://doi.org/10.1177\%2F0963662520908534

Rutjens, B. T., Sengupta, N., van der Lee, R., van Koningsbruggen, G. M., Martens, J. P., Rabelo, A., \& Sutton, R. M. (2021a) Science Skepticism Across 24 Countries. Social Psychological \& Personality Science. Advance online publication. https://doi.org/10.1177\%2F19485506211001329

Rutjens, B.; van der Linden, S. \& van der Lee, R. (2021b). Science skepticism in times of COVID-19. Group Processes \& Intergroup Relations, 24(2), 276-283. https://doi.org/10.1177\%2F1368430220981415

Rutjens, B.; Heine, S.; Sutton, R. \& van Harreveld, F. (2018a). Attitudes towards science. In J. M. Olson (Ed.), Advances in experimental social psychology (pp. 125-165). Academic Press.

Rutjens, B; Sutton, R. \& van der Lee, R. (2018b). Not All Skepticism is Equal: Exploring the Ideological Antecedents of Science Acceptance and Rejection. Personality and Social Psychology Bulletin, 44(3), 384-405. https://doi.org/10.1177\%2F0146167217741314 
Salomo, K. (2019). The residential context as source of deprivation: Impacts on the local political culture. Evidence from the East German state Thuringia. Political Geography, 69, 103-117. https://doi.org/10.1016/j.polgeo.2018.07.001

Schaeffer, K. (2020, April 8). Nearly three-in-ten Americans believe COVID-19 was made in a lab. Pew Research Center. https://www.pewresearch.org/facttank/2020/04/08/nearly-three-in-ten-americans-believe-covid-19-was-made-in-a-lab/

Schmitt, K.; Best, H. \& Reiser, M. (in press). Thüringen-Monitor 2000-2020 [data set]. GESIS (Leibniz Institute for the Social Sciences) Data archive. Cologne.

Stanley, M. L., Barr, N., Peters, K. \& Seli, P. (2020). Analytic-thinking predicts hoax beliefs and helping behaviors in response to the COVID-19 pandemic. Thinking \& Reasoning, 1-14. https://doi.org/10.1080/13546783.2020.1813806

Statista (2021, January). Durchschnittsalter der Bevölkerung in Deutschland nach Bundesländern im Jahr 2019 [Average age of the population in the German states in 2019].

https://de.statista.com/statistik/daten/studie/1093993/umfrage/durchschnittsalter-derbevoelkerung-in-deutschland-nach-bundeslaendern/

Tsai, L. L., Morse, B. S. \& Blair, R. A. (2020). Building Credibility and Cooperation in LowTrust Settings: Persuasion and Source Accountability in Liberia During the 20142015 Ebola Crisis. Comparative Political Studies, 53(10-11), 1582-1618. https://doi.org/10.1177\%2F0010414019897698

Uscinski, J. E., Enders, A. M., Klofstad, C., Seelig, M., Funchion, J., Everett, C., Wuchty, S., Premaratne, K. \& Murthi (2020). Why do people believe COVID-19 conspiracy theories? The Harvard Kennedy School Misinformation Review, Special Issue: Covid19. https://misinforeview.hks.harvard.edu/wpcontent/uploads/2020/04/FORMATTED COVID-19 conspiracytheories..pdf

Van Prooijen, J.-W. \& Douglas, K. M. (2017). Conspiracy theories as part of history: The role of societal crisis situations. Memory Studies, 10(3), 323-333. https://doi.org/10.1177\%2F1750698017701615

Weisskircher, M. (2020). The Strength of Far-Right AfD in Eastern Germany: The East-West Divide and the Multiple Causes behind 'Populism'. The Political Quarterly, 91(3), 614-622. https://doi.org/10.1111/1467-923X.12859

WHO (2020, February 15). Speech of Director-General of the World Health Organization Tedros Adhanom at the Munich Security Conference. Manuscript: https://www.who.int/director-general/speeches/detail/munich-security-conference 
Zick, A. \& Küpper, B. (2021). Die geforderte Mitte. Rechtsextreme und demokratiegefährdende Einstellungen in Deutschland 2020/21. Dietz-Verlag. 


\section{Appendix}

Table 3: Coding of the variables in the study

\begin{tabular}{|c|c|}
\hline Variable & Operationalisation/survey items (English translation) \\
\hline $\begin{array}{l}\text { Corona scepticism } \\
\text { (DV) }\end{array}$ & $\begin{array}{l}\text { 'The virus is actually no worse than the flu' (four-point scale: fully agree, } \\
\text { mostly agree, mostly disagree, fully disagree) } \\
\text { COVID-19 scepticism index consisting of the item mentioned above and } \\
\text { two additional items: } \\
\text { 'The danger posed by the coronavirus is greatly exaggerated by the media' } \\
\text { 'I trust my feelings about dealing with Corona more than so-called experts' }\end{array}$ \\
\hline $\begin{array}{l}\text { Risk perception } \\
\text { (health) }\end{array}$ & $\begin{array}{l}\text { 'How high do you rate the risk of the Corona crisis for your own health?' } \\
\text { (five-point scale: no risk, very small risk, small risk, high risk, very high risk) }\end{array}$ \\
\hline $\begin{array}{l}\text { Risk perception } \\
\text { (personal economic } \\
\text { situation) }\end{array}$ & $\begin{array}{l}\text { 'How high do you rate the risk of the Corona crisis for your personal } \\
\text { economic situation?' (five-point scale: no risk, very small risk, small risk, } \\
\text { high risk, very high risk) }\end{array}$ \\
\hline $\begin{array}{l}\text { Left-right self- } \\
\text { placement }\end{array}$ & $\begin{array}{l}\text { 'In politics one often talks about 'left' and 'right'. Where would you place } \\
\text { yourself: very far-left, fairly far-left, rather left, rather right, fairly far-right, } \\
\text { very far-right?'; participants could also spontaneously indicated that they } \\
\text { would place themselves in the middle. }\end{array}$ \\
\hline Party identification & $\begin{array}{l}\text { 'Generally speaking, do you tend towards a particular party? If yes, towards } \\
\text { which one?' }\end{array}$ \\
\hline Far-right attitudes & $\begin{array}{l}\text { Mean scale, comprised of the following items (that were each rated on a } \\
\text { four-point scale ranging from 'fully agree' to 'fully disagree'): } \\
\text { Ethnocentrism: } \\
\text { Foreigners only come to Germany to abuse the welfare state. } \\
\text { Germany is to an dangerous degree dominated by foreigners. } \\
\text { Other countries don't match Germany's achievements. } \\
\text { What we need in our country is to forcefully and aggressively assert } \\
\text { German interests toward foreign countries. } \\
\text { Neo-Nazi ideology: } \\
\text { National Socialism had its positive aspects. } \\
\text { For the national interest, a dictatorship is under certain conditions the best } \\
\text { form of government. } \\
\text { The Jews are just peculiar and don't really fit in with us. } \\
\text { There is worthy and unworthy life. } \\
\text { As in nature, in society the fittest should win. } \\
\text { Foreigners ought to marry only among themselves. }\end{array}$ \\
\hline Conspiracy belief & $\begin{array}{l}\text { There are secret organizations that have a great influence on political } \\
\text { decisions during the Corona crisis (four-point scale: fully agree, mostly } \\
\text { agree, mostly disagree, fully disagree) }\end{array}$ \\
\hline $\begin{array}{l}\text { Trust in the } \\
\text { government }\end{array}$ & $\begin{array}{l}\text { 'I now read to you a number of public facilities. Please tell me for each one } \\
\text { whether you trust it fully, largely trust it, partially trust it, rather not trust it, } \\
\text { or not trust it at all. How is that with the federal government' }\end{array}$ \\
\hline Trust in the media & $\begin{array}{l}\text { 'I now read to you a number of public facilities. Please tell me for each one } \\
\text { whether you trust it fully, largely trust it, partially trust it, rather not trust it, } \\
\text { or not trust it at all. How is that with the media' }\end{array}$ \\
\hline $\begin{array}{l}\text { Trust in public health } \\
\text { authority (RKI) }\end{array}$ & $\begin{array}{l}\text { 'I now read to you a number of public facilities. Please tell me for each one } \\
\text { whether you trust it fully, largely trust it, partially trust it, rather not trust it, } \\
\text { or not trust it at all. How is that with the Robert Koch Institute' }\end{array}$ \\
\hline
\end{tabular}


Table 4. Sample information; descriptive statistics of control variables

\begin{tabular}{lcc}
\hline & absolute & per cent \\
\hline total sample size & 1,110 & \\
gender & & \\
male & 546 & 49 \\
female & 564 & 51 \\
age & & \\
$18-24$ years & 69 & 6 \\
$25-34$ years & 119 & 11 \\
$35-44$ years & 169 & 15 \\
$45-59$ years & 252 & 23 \\
60 years and above & 500 & 45 \\
education & & \\
without school leaving certificate or lowest formal qualification $(8-$ & 313 & 28 \\
9 years of schooling) & & \\
intermediary secondary qualification (10 years of schooling), & 532 & 48 \\
qualification to study at a university & 113 & 10 \\
university degree & 150 \\
affectedness by COVID-19 & & 14 \\
yes & & \\
no & & \\
no, but belong to a high-risk group & 131 & 12 \\
political interest & 761 & 69 \\
very strong & 216 & 19 \\
strong & & \\
medium & & \\
little & & \\
very little & 11 \\
\hline
\end{tabular}




\section{Supplementary Materials for}

\section{'It is not worse than a flu' - COVID-19 Scepticism and the Role of Trust and Far-Right Attitudes in Germany}

This document includes:

Figures S.1-S.3

Tables S.1-S.5 
Figure S.1 COVID-19 cases in Thuringia

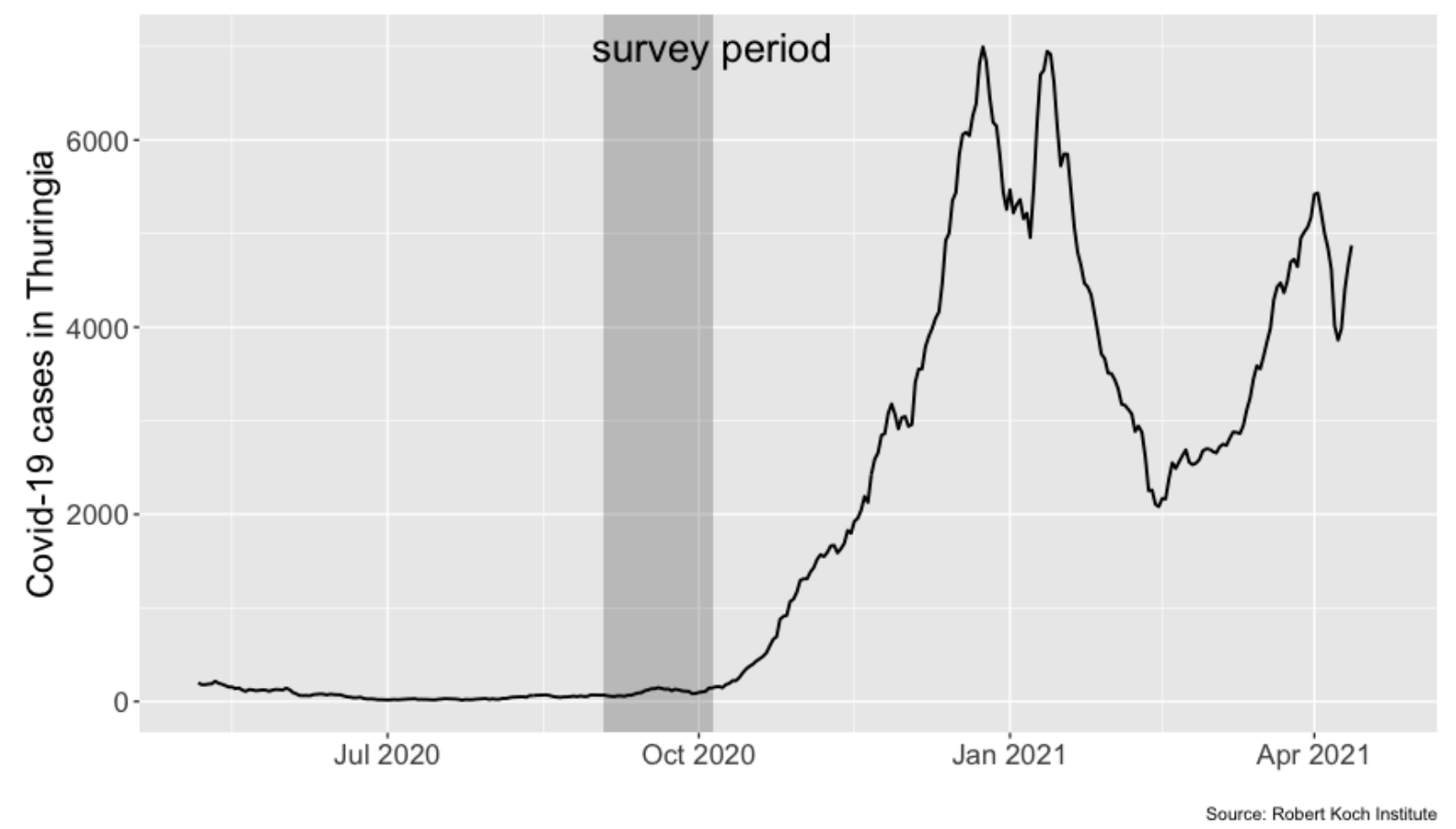

Figure S.2 Distribution of COVID-19 sceptics along the left-right dimension

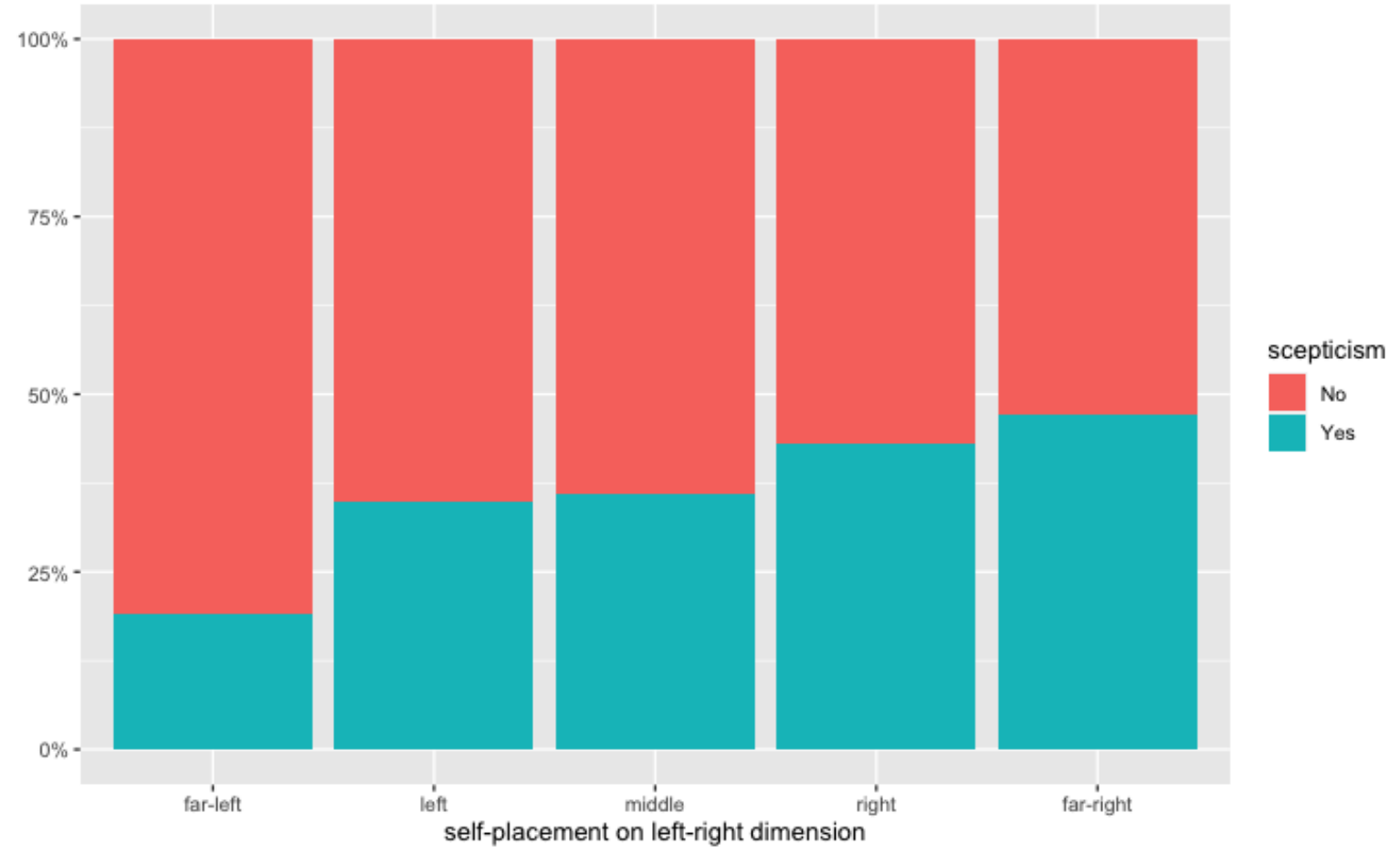


Figure S.3 Distribution of COVID-19 sceptics according to party identification

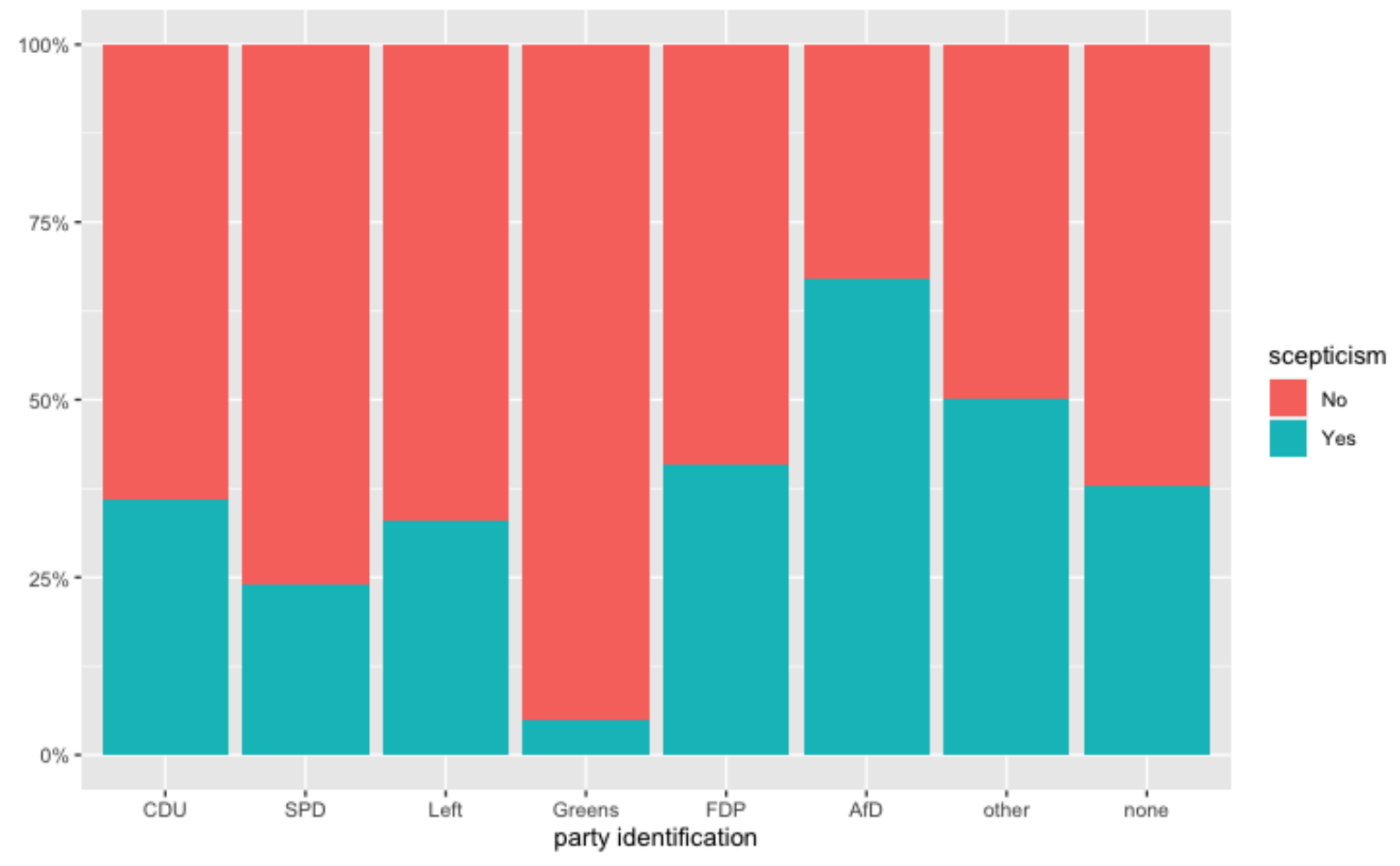


Table S.1 OLS regression full model (unstandardised regression coefficients; standard error in parentheses)

The dependent variable is an additive index computed of three variables. Next to the variable that was already used in the logistic regression analysis in the main section of the paper 'the virus is actually not worse than the flu'; the two additional items are: 'The danger posed by the coronavirus is greatly exaggerated by the media' and 'I trust my feelings about dealing with Corona more than so-called experts'. All items were answered on a four-point scale ('fully agree'; 'mostly agree'; 'mostly disagree'; 'fully disagree').

Dependent variable: COVID-19 scepticism (3-item index)

\begin{tabular}{|c|c|}
\hline Regressors & Model (1) \\
\hline Risk perception (health) (high risk) & $\begin{array}{l}-0.546^{*} \\
(0.243)\end{array}$ \\
\hline Risk perception (pers. econ. situation) (high risk) & $\begin{array}{c}-0.476 \\
(0.283)\end{array}$ \\
\hline Far-right attitudes & $\begin{array}{c}1.425^{* * *} \\
(0.264)\end{array}$ \\
\hline Conspiracy belief & $\begin{array}{l}0.727 * \\
(0.291)\end{array}$ \\
\hline Trust federal government (medium) & $\begin{array}{l}-0.608 \\
(0.323)\end{array}$ \\
\hline Trust federal government (high) & $\begin{array}{c}-1.278 * * \\
(0.411)\end{array}$ \\
\hline Trust media (medium) & $\begin{array}{c}-0.210 \\
(0.308)\end{array}$ \\
\hline Trust media (high) & $\begin{array}{l}-0.176 \\
(0.369)\end{array}$ \\
\hline Trust Robert Koch Institute (medium) & $\begin{array}{c}-1.734 * * * \\
(0.439)\end{array}$ \\
\hline Trust Robert Koch Institute (high) & $\begin{array}{c}-2.796 * * * \\
(0.368)\end{array}$ \\
\hline Age & $\begin{array}{c}-0.013 \\
(0.007)\end{array}$ \\
\hline Gender (female) & $\begin{array}{c}0.112 \\
(0.244)\end{array}$ \\
\hline Education (A-levels or higher) & $\begin{array}{l}-0.026 \\
(0.184)\end{array}$ \\
\hline Political interest & $\begin{array}{c}-0.188 \\
(0.132)\end{array}$ \\
\hline Affectedness by COVID-19 (no) & $\begin{array}{c}0.355 \\
(0.264)\end{array}$ \\
\hline Affectedness by COVID-19 (no; but risk group) & $\begin{array}{c}-0.094 \\
(0.378)\end{array}$ \\
\hline Intercept & $\begin{array}{c}5.560 * * * \\
(0.816) \\
\end{array}$ \\
\hline Observations & 787 \\
\hline adjusted R2 & 0.496 \\
\hline
\end{tabular}


Table S.2 Logistic regression full model ( $D V=$ dummy from 3 items); OR with 95\% confidence interval

The dependent variable is an additive index computed of three variables. Next to the variable that was already used in the logistic regression analysis in the main section of the paper "the virus is actually not worse than the flu'; the two additional items are: 'The danger posed by the coronavirus is greatly exaggerated by the media' and 'I trust my feelings about dealing with Corona more than so-called experts'. Thus; an individual receives the value $(1=$ COVID-19 sceptic); when (s)he responded 'fully agree' or 'mostly agree' on all three items.

Dependent variable: dummy COVID-19 scepticism (3 items)

\begin{tabular}{|c|c|}
\hline Regressors & Model (1) \\
\hline \multirow[t]{2}{*}{ Risk perception (health) (high risk) } & $0.511 *$ \\
\hline & {$[0.278 ; 0.910]$} \\
\hline \multirow{2}{*}{ Risk perception (pers. econ. situation) (high risk) } & 0.674 \\
\hline & {$[0.353 ; 1.256]$} \\
\hline \multirow[t]{2}{*}{ Far-right attitudes } & $3.457 * * *$ \\
\hline & {$[2.252 ; 5.396]$} \\
\hline \multirow[t]{2}{*}{ Conspiracy belief } & $1.826 *$ \\
\hline & {$[1.118 ; 2.977]$} \\
\hline \multirow[t]{2}{*}{ Trust federal government (medium) } & 0.760 \\
\hline & {$[0.425 ; 1.361]$} \\
\hline \multirow[t]{2}{*}{ Trust federal government (high) } & $0.496 *$ \\
\hline & {$[0.249 ; 0.989]$} \\
\hline \multirow{2}{*}{ Trust media (medium) } & 0.809 \\
\hline & {$[0.451 ; 1.453]$} \\
\hline \multirow{2}{*}{ Trust media (high) } & 0.914 \\
\hline & {$[0.453 ; 1.819]$} \\
\hline \multirow[t]{2}{*}{ Trust Robert Koch Institute (medium) } & $0.309 * *$ \\
\hline & {$[0.139 ; 0.669]$} \\
\hline \multirow[t]{2}{*}{ Trust Robert Koch Institute (high) } & $0.096^{* * *}$ \\
\hline & {$[0.045 ; 0.200]$} \\
\hline \multirow[t]{2}{*}{ Age } & 0.998 \\
\hline & {$[0.983 ; 1.012]$} \\
\hline \multirow[t]{2}{*}{ Gender (female) } & 1.550 \\
\hline & {$[0.989 ; 2.443]$} \\
\hline \multirow[t]{2}{*}{ Education (A-levels or higher) } & 1.051 \\
\hline & {$[0.585 ; 1.858]$} \\
\hline \multirow[t]{2}{*}{ Political interest } & 0.932 \\
\hline & {$[0.746 ; 1.162]$} \\
\hline \multirow{2}{*}{ Affectedness by COVID-19 (no) } & 1.589 \\
\hline & {$[0.719 ; 3.732]$} \\
\hline \multirow[t]{2}{*}{ Affectedness by COVID-19 (no; but risk group) } & 0.831 \\
\hline & {$[0.308 ; 2.298]$} \\
\hline \multirow[t]{2}{*}{ Intercept } & $0.153 *$ \\
\hline & {$[0.028 ; 0.794]$} \\
\hline Observations & 787 \\
\hline Log Likelihood & -232.677 \\
\hline AIC & 499.353 \\
\hline Nagelkerke Pseudo-R2 & 0.384 \\
\hline
\end{tabular}


Table S.3 Logistic regression full model with left-right self-placement (model 1) or party ID (model 2) as operationalisation of political ideology; OR with $95 \%$ confidence interval

The reference category used for party identification is the Social Democratic party (SPD).

\begin{tabular}{|c|c|c|}
\hline \multicolumn{3}{|c|}{ Dependent variable: dummy COVID-19 scepticism ('the virus is actually not worse than the flu') } \\
\hline Regressors & Model (1) & Model (2) \\
\hline \multirow[t]{2}{*}{ Risk perception (health) (high risk) } & 0.636 & $0.459 * * *$ \\
\hline & {$[0.398 ; 1.002]$} & {$[0.286 ; 0.724]$} \\
\hline \multirow{2}{*}{ Risk perception (pers. econ. situation) (high risk) } & 0.970 & 0.805 \\
\hline & {$[0.582 ; 1.599]$} & {$[0.479 ; 1.339]$} \\
\hline \multirow[t]{2}{*}{ Left-right self-placement } & 0.854 & \\
\hline & {$[0.694 ; 1.049]$} & \\
\hline \multirow[t]{2}{*}{ Party ID (AfD) } & & 1.785 \\
\hline & & {$[0.504 ; 6.853]$} \\
\hline \multirow[t]{2}{*}{ Party ID (CDU) } & & 1.759 \\
\hline & & {$[0.680 ; 5.103]$} \\
\hline \multirow{2}{*}{ Party ID (FDP) } & & 1.675 \\
\hline & & {$[0.318 ; 8.677]$} \\
\hline \multirow[t]{2}{*}{ Party ID (Greens) } & & 0.235 \\
\hline & & {$[0.037 ; 1.099]$} \\
\hline \multirow[t]{2}{*}{ Party ID (Left) } & & 1.022 \\
\hline & & {$[0.393 ; 2.964]$} \\
\hline \multirow[t]{2}{*}{ Party ID (none) } & & 1.254 \\
\hline & & {$[0.518 ; 3.458]$} \\
\hline \multirow[t]{2}{*}{ Party ID (other) } & & $4.307 *$ \\
\hline & & {$[1.321 ; 15.093]$} \\
\hline \multirow[t]{2}{*}{ Conspiracy belief } & $2.138 * * *$ & $2.419 * * *$ \\
\hline & {$[1.413 ; 3.238]$} & {$[1.603 ; 3.663]$} \\
\hline \multirow[t]{2}{*}{ Trust federal government (medium) } & 0.641 & 0.734 \\
\hline & {$[0.378 ; 1.085]$} & {$[0.428 ; 1.259]$} \\
\hline \multirow[t]{2}{*}{ Trust federal government (high) } & $0.315^{* * *}$ & $0.337 * * *$ \\
\hline & {$[0.177 ; 0.559]$} & {$[0.189 ; 0.600]$} \\
\hline \multirow[t]{2}{*}{ Trust media (medium) } & 0.889 & 0.768 \\
\hline & {$[0.554 ; 1.429]$} & {$[0.475 ; 1.246]$} \\
\hline \multirow[t]{2}{*}{ Trust media (high) } & 1.310 & 1.450 \\
\hline & {$[0.763 ; 2.258$} & {$[0.833 ; 2.538]$} \\
\hline \multirow[t]{2}{*}{ Trust Robert Koch Institute (medium) } & $0.241 * * *$ & $0.313 * * *$ \\
\hline & {$[0.097 ; 0.552]$} & {$[0.130 ; 0.714]$} \\
\hline \multirow[t]{2}{*}{ Trust Robert Koch Institute (high) } & $0.074 * * *$ & $0.135 * * *$ \\
\hline & {$[0.030 ; 0.165]$} & {$[0.058 ; 0.296]$} \\
\hline \multirow[t]{2}{*}{ Age } & 1.008 & 1.007 \\
\hline & {$[0.997 ; 1.019]$} & {$[0.996 ; 1.019]$} \\
\hline \multirow[t]{2}{*}{ Gender (female) } & 0.748 & 1.008 \\
\hline & {$[0.511 ; 1.091]$} & {$[0.690 ; 1.471]$} \\
\hline \multirow[t]{2}{*}{ Education (A-levels or higher) } & 0.817 & 0.905 \\
\hline & {$[0.517 ; 1.280]$} & {$[0.574 ; 1.420]$} \\
\hline \multirow[t]{2}{*}{ Political interest } & $0.589 * * *$ & $0.693 * * *$ \\
\hline & {$[0.482 ; 0.714]$} & {$[0.573 ; 0.834]$} \\
\hline Affectedness by COVID-19 (no) & 1.632 & 1.920 \\
\hline & {$[0.882 ; 3.121]$} & {$[1.005 ; 3.825]$} \\
\hline Affectedness by COVID-19 (no; but risk group) & 0.844 & 0.975 \\
\hline & {$[0.379 ; 1.894]$} & {$[0.435 ; 2.223]$} \\
\hline Intercept & $34.432 * * *$ & 4.520 \\
\hline & [7.065 180.437] & {$[0.878 ; 22.840]$} \\
\hline Observations & 802 & 778 \\
\hline Log Likelihood & -321.868 & -334.837 \\
\hline
\end{tabular}


AIC

Nagelkerke Pseudo-R2
677.736

0.332
715.674

0.335 
Table S.4 Logistic regression full model (5-item scales instead of dummies); OR with 95\% confidence interval

5-item scales instead of dummies were used for the variables risk perception (health); risk perception (personal economic situation); trust in the federal government; trust in the media; trust in the Robert Koch Institute.

Dependent variable: dummy COVID-19 scepticism ('the virus is actually not worse than the flu')

\begin{tabular}{lc}
\hline Regressors & Model $(1)$ \\
\hline Risk perception (health) & $0.743^{* *}$ \\
Risk perception (pers. econ. situation) & $0.616 ; 0.894]$ \\
& 0.924 \\
Far-right attitudes & {$[0.773 ; 1.103$} \\
& $2.876^{* * *}$ \\
Conspiracy belief & {$[1.970 ; 4.241]$} \\
& $2.161 * * *$ \\
Trust federal government & {$[1.427 ; 3.279]$} \\
& $0.701 * *$ \\
Trust media & {$[0.561 ; 0.874]$} \\
Trust Robert Koch Institute & $1.321^{* *}$ \\
& {$[1.070 ; 1.640]$} \\
Age & $0.465^{* * *}$ \\
& {$[0.369 ; 0.579]$} \\
Gender (female) & 0.998 \\
Education (A-levels or higher) & {$[0.985 ; 1.010]$} \\
Political interest & 1.065 \\
& {$[0.725 ; 1.564]$} \\
Affectedness by COVID-19 (no) & 1.074 \\
Affectedness by COVID-19 (no; but risk group) & {$[0.671 ; 1.713]$} \\
Intercept & $0.755^{* *}$ \\
& {$[0.621 ; 0.914]$} \\
Observations & 1.202 \\
Log Likelihood & {$[0.638 ; 2.337]$} \\
AIC & 0.746 \\
Nagelkerke Pseudo-R2 & {$[0.329 ; 1.706]$} \\
& $6.011^{*}$ \\
& {$[1.195 ; 31.140]$} \\
811 \\
\end{tabular}


Table S.5 Logistic regression full model (alternative operationalisation of economic threat); OR with $95 \%$ confidence interval

Economic risk perception was operationalised with the alternative item: 'My personal economic situation has significantly worsened as a result if the Corona crisis' (answers on a four-point scale ranging from 'fully agree' to 'fully disagree'; recoded as a dummy variable with $1=$ 'fully agree'/'mostly agree' and $0=$ 'mostly disagree'/'fully disagree').

Dependent variable: dummy COVID-19 scepticism ('the virus is actually not worse than the flu')

\begin{tabular}{|c|c|}
\hline Regressors & Model (1) \\
\hline Risk perception (health) (high risk) & $\begin{array}{c}0.516^{* *} \\
{[0.324 ; 0.811]}\end{array}$ \\
\hline Affectedness of pers. econ. situation (yes) & $\begin{array}{c}1.081 \\
{[0.646 ; 1.793]}\end{array}$ \\
\hline Far-right attitudes & $\begin{array}{c}2.809 * * * \\
{[1.921 ; 4.148]}\end{array}$ \\
\hline Conspiracy belief & $\begin{array}{c}1.854 * * \\
{[1.212 ; 2.835]}\end{array}$ \\
\hline Trust federal government (medium) & $\begin{array}{c}0.787 \\
{[0.462 ; 1.342]}\end{array}$ \\
\hline Trust federal government (high) & $\begin{array}{c}0.504^{*} \\
{[0.281 ; 0.907]}\end{array}$ \\
\hline Trust media (medium) & $\begin{array}{c}0.940 \\
{[0.576 ; 1.539]}\end{array}$ \\
\hline Trust media (high) & $\begin{array}{c}1.743^{*} \\
{[1.008 ; 3.040]}\end{array}$ \\
\hline Trust Robert Koch Institute (medium) & $\begin{array}{c}0.225^{* * *} \\
{[0.095 ; 0.497]}\end{array}$ \\
\hline Trust Robert Koch Institute (high) & $\begin{array}{c}0.090 * * * \\
{[0.040 ; 0.188]}\end{array}$ \\
\hline Age & $\begin{array}{c}0.998 \\
{[0.987 ; 1.010]}\end{array}$ \\
\hline Gender (female) & $\begin{array}{c}0.944 \\
{[0.645 ; 1.380]}\end{array}$ \\
\hline Education (A-levels or higher) & $\begin{array}{c}1.039 \\
{[0.651 ; 1.651]}\end{array}$ \\
\hline Political interest & $\begin{array}{c}0.786^{*} \\
{[0.648 ; 0.948]}\end{array}$ \\
\hline Affectedness by COVID-19 (no) & $\begin{array}{c}1.543 \\
{[0.790 ; 3.163]}\end{array}$ \\
\hline Affectedness by COVID-19 (no; but risk group) & $\begin{array}{c}0.923 \\
{[0.397 ; 2.191]}\end{array}$ \\
\hline Intercept & $\begin{array}{c}1.026 \\
{[0.238 ; 4.492]}\end{array}$ \\
\hline Observations & 813 \\
\hline Log Likelihood & -316.784 \\
\hline AIC & 667.568 \\
\hline Nagelkerke Pseudo-R2 & 0.366 \\
\hline
\end{tabular}

